\title{
Pengaruh bahan kampas rem terhadap respon getaran pada sistem rem cakram
}

\author{
Muhammad Mushlih Elhafid', Didik Djoko Susilo', Purwadi Joko Widodo
}

${ }^{1}$ Departemen Teknik Mesin, FakultasTeknik, Universitas Sebelas Maret Jl. Ir. Sutami No. 36A Surakarta

Email korespondensi: purwadi_joko@uns.ac.id

\begin{abstract}
Abstrak
Penelitian ini bertujuan untuk mengetahui pengaruh bahan bantalan rem terhadap respon getaran sistem rem cakram terhadap berbagai variasi kondisi pengereman. Variasi bahan bantalan rem pada penelitian ini seperti logam, non-asbes, dan keramik. Variasi operasi pengereman seperti kecepatan putaran disk dan tekanan pengereman. Setiap bahan bantalan rem diuji dengan variasi putaran cakram 425, 637, 850, 1062 rpm dan variasi tekanan 0,5 bar; 1 bar; 1,5 bar. Selanjutnya karakteristik dinamik dari rem pad telah diuji dengan menggunakan metode Analisis Modal Percobaan. Hasil penelitian menunjukkan bahwa jenis bahan brake pad, putaran cakram, dan tekanan pengereman berpengaruh terhadap respon getaran sistem rem cakram. Peningkatan kecepatan putaran cakram dan tekanan pengereman akan meningkatkan gaya eksitasi sehingga nilai amplitudo getaran pada sistem pengereman meningkat. Penggunaan keramik rem pad juga menunjukkan amplitudo getaran terendah untuk seтиa variasi putaran disk dan tekanan pengereman. Karena pad rem keramik memiliki frekuensi alam paling rendah, maka nilai rasio redamannya tinggi, sehingga terjadi penurunan amplitudo getaran yang terjadi pada sistem pengereman
\end{abstract}

Kata kunci: rem cakram, respons getaran, material kampas rem, amplitudo getaran.

\begin{abstract}
This study aims to determine the effect of brake pads material to the vibration response of disc brake system on many variety of braking conditions. The variations of brake pads material on this research such as metallic, non-asbes, and ceramic. The variations of braking operation such as speed of disc rotation and braking pressure. Each brake pads material tested by variation of disc rotation 425, 637, 850, 1062 rpm and pressure variation 0,5 bar; 1 bar; 1,5 bar. Furthermore, the dynamic characteristics of brake pad had been tested by using the method of Modal Analysis Experiment. The results showed that the type of brake pad materials, disc rotation, and braking pressure affect to vibration response of disc brake system. Increasing speed of disc rotation and braking pressure will increase the excitation force causing value amplitude of vibration in the braking system increases. Usage of brake pad ceramic also showed the lowest amplitude of vibration for all variations of disc rotation and braking pressure. Because the ceramic brake pad have the lowest natural frequency, then the value of the damping ratio is high, so that decreasing amplitude of vibration that occurs in the braking system.
\end{abstract}

Keywords: disc brake, vibration response, brake pad material, amplitude of vibration.

\section{Pendahuluan}

Rem merupakan suatu komponen yang sangat penting pada kendaraan bermotor yang berfungsi untuk mereduksi energi gerak kendaraan sehingga akan memperlambat atau menghentikan laju kendaraan, oleh karena itu keselamatan jiwa manusia sangat tergantung pada komponen ini. Rem cakram merupakan salah satu jenis rem yang secara luas digunakan pada sistem pengereman kendaraan modern. Pada prinsipnya rem bekerja karena adanya gesekan antara piringan (disc) dengan kampas rem (brake pad) pada saat kedua komponen ini berkontak. Dengan adanya gaya gesek tersebut, maka akan timbul getaran, panas dan bunyi saat rem beroperasi. Getaran yang timbul akibat gesekan kampas rem dengan piringan rem tersebut, akan sangat mengganggu kenyamanan berkendara dan juga dapat menyebabkan kinerja dari sistem pengereman kurang maksimal. Untuk menghindari pengaruh negatif getaran tersebut, maka perlu dilakukan identifikasi getaran yang terjadi pada kampas rem saat beroperasi.

Terdapat berbagai jenis bahan kampas rem yang ada dipasaran seperti metalik, non-asbes, dan keramik, maka dapat dilakukan penelitian mengenai pengaruh bahan kampas rem terhadap respon getaran pada sistem rem cakram. Pengujian terhadap variasi bahan kampas rem perlu dilakukan dengan membandingkan kondisi getaran pada saat pengereman dan menganalisis parameter-parameter yang berpengaruh terhadap respon getaran yang terjadi seperti variasi kecepatan putaran piringan rem dan tekanan pengereman. Dengan membandingkan nilai amplitudo getaran keseluruhan sistem pengereman untuk setiap bahan kampas rem yang digunakan, maka dapat diketahui bahan kampas rem yang memberikan respon getaran terendah, yang nantinya 
berguna untuk memberikan informasi kepada masyarakat agar memilih bahan kampas rem yang mampu memberikan getaran paling rendah pada sistem pengereman, sehingga tidak mengganggu kenyamanan berkendara dan membuat kerja sistem pengereman menjadi maksimal.

Penelitian getaran pada sistem pengereman khususnya sistem rem cakram telah banyak dilakukan. [1] melakukan penelitian tentang getaran dan suara yang terjadi pada rem cakram ketika beroperasi. Pada penelitian ini dilakukan dua tahap, tahap pertama modal analysis untuk mendapatkan frekuensi pribadi masing-masing komponen sistem pengereman. Tahap kedua pengukuran respon getaran ketika rem beroperasi dengan pemasangan sensor accelerometer dan microphone. Penelitian ini dilakukan dengan variasi kecepatan putar piringan, tekanan pengereman, dan skema pemasangan rem. Hasil pengujian menunjukkan bahwa didapatkan pola respon getaran yang berbeda dengan adanya perubahan kondisi operasional rem. Ditemukan fenomena stick-slip dan pola respon getaran yang menyebabkan bunyi melengking pada skema A (penguncian baut baik, memakai pegas anti ratlle dan tanpa lapisan pengotor) dan skema $\mathrm{C}$ (penguncian baut baik, tanpa pegas anti ratlle dan tanpa lapisan pengotor).

Pada variasi kecepatan putaran piringan rem (disc) dan tekanan pengereman juga akan mempengaruhi getaran yang terjadi pada sistem rem cakram, seperti pernyataan [2] melakukan penelitian tentang kebisingan pada interior kendaraan dari sistem rem cakram. Penelitian ini dilakukan dengan variasi kecepatan 1,3 km/jam, 1,9 km/jam, dan 2,9 km/jam dan variasi tekanan 0,0 bar, 1,8 bar, 3,3 bar, dan 5,0 bar. Hasil penelitian yang dilakukan oleh [2] menunjukkan bahwa level kebisingan pada interior kendaran semakin meningkat seiring dengan meningkatnya tekanan pengereman dan level kebisingan pada interior kendaran juga semakin meningkat seiring dengan meningkatnya kecepatan kendaraan.

Dengan tekanan pengereman yang bervariasi, maka akan mempengaruhi kekakuan antara kampas rem dan piringan rem (disc) di area kontak (kekakuan kontak), seperti yang dinyatakan oleh [6]. [6] melakukan penelitian tentang pengaruh kekakuan dinamis di daerah kontak pada rem cakram. Penelitian ini dilakukan dengan mesin tes squeal, yaitu dengan memberikan tekanan konstan dan gaya eksitasi pada kampas rem, kemudian dianalisis menggunakan surface contact analysis model. Hasil pengukuran menunjukkan bahwa kekakuan kontak tergantung pada tekanan pengereman untuk tiap kampas. Hasil dari pengujian squeal menunjukkan bahwa frekuensi squeal menjadi lebih tinggi karena tekanan pengereman yang semakin besar.
Selain kekakuan kontak antara kampas rem dan piringan rem (disc), kekakuan kampas rem juga mempengaruhi getaran yang terjadi pada sistem rem cakram, seperti yang dinyatakan oleh [5]. [3] melakukan penelitian tentang pengaruh ketebalan kampas rem (brake pad) terhadap squeal pada rem cakram. Pada penelitian ini pengujian squeal di analisis dengan mengacu pada kekakuan dinamis kampas rem, yaitu dengan menganalisis sinyal getaran yang berupa frekuensi dan amplitudo. Dan hasil dari analisis ini menunjukkan bahwa kekakuan kampas rem akan semakin besar jika ketebalan kampas rem semakin menipis. Selain itu penelitian ini juga dianalisis menggunakan surface contact analysis model agar menghasilkan kekakuan kampas rem, dengan cara mendistribusikan perbedaan dimensi pada arah ketebalan kampas dengan jarak dari permukaan kontak sampai pusat putaran kampas. Dan hasil dari analisis ini menunjukkan bahwa jika kampas rem semakin kaku maka squeal frequency akan semakin besar.

\section{Rem Cakram}

Rem cakram adalah suatu jenis sistem rem yang terdiri dari piringan yang terbuat dari besi tuang, caliper, dan kampas rem. Sistem kerja dari rem cakram ini yaitu piringan (disc) dijepit oleh kampas rem (brake pad) yang didorong oleh sebuah torak yang ada dalam silinder roda. Untuk menjepit piringan ini membutuhkan gaya yang besar, gaya ini dihasilkan dari sistem hidraulik. Komponen rem yang bergesekan ini harus tahan terhadap gesekan (tidak mudah aus), tahan panas, dan tidak mudah berubah bentuk pada saat bekerja dalam suhu tinggi.

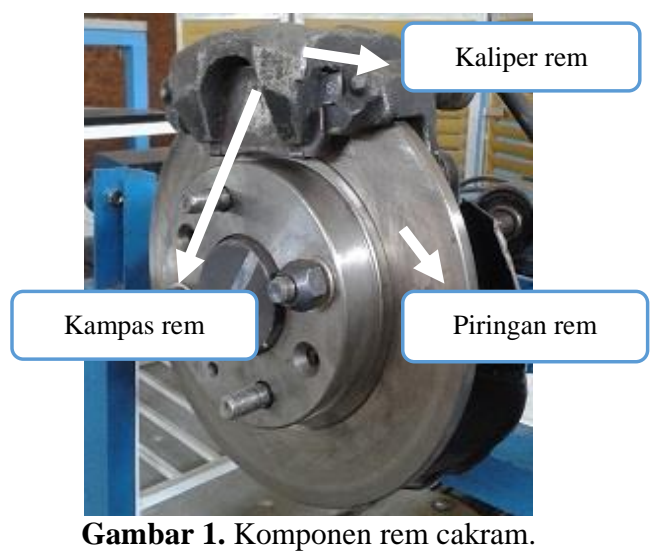

Terdapat tiga jenis bahan kampas rem yang terdapat dipasaran yaitu sebagai berikut [7] :

\section{Kampas Rem Non-Asbes}

Kampas rem non-asbes terdiri dari resin yang digunakan untuk memperkuat friction material dan memberikan kekuatan pada kampas rem. Resin yang biasanya dipakai adalah aramyd, rockwool, cellulose, atau fiberglass. Friction material non-asbes mengandung serat baja kurang dari 20\%. Berikut kandungan kampas rem non-asbes : iron, graphite, cellulose fiber, calcium carbonat, dan free phenol. 


\section{Kampas Rem Keramik}

Kampas rem keramik tidak mengandung serat baja. Sebaliknya, formulasi ini menggunakan serat keramik dan tembaga untuk mengelola disipasi panas. Berikut kandungan yang ada pada kampas rem keramik : Aluminum, Antimony Trisulfide, Barium Sulfate, Calcium Hydroxide, Copper, Magnesium Oxide, Molybdenum Disulfide, Magnesium Potassium Titanium Oxide, Graphite, Man-made Vitreous Fibers, Crystalline Silica, dan Misc. Non-hazardous Ingredients.

\section{Kampas Rem Metalik}

Kampas rem metalik terbuat dari steel fiber sebagai penguat serat. Kebanyakan friction material metalik mengandung setidaknya $\geq 60 \%$ serat serat baja (steel fiber). Berikut kandungan dari kampas rem metalik : graphite, friction particle, steel fiber, iron powder, barium sulfat, magnesium oxide, resin, dan binder.

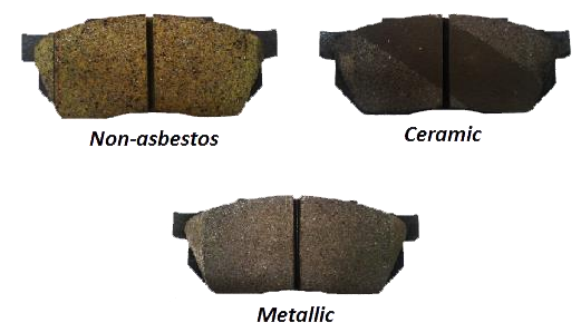

Gambar 2. Kampas rem cakram.

\section{Metode}

Pada penelitian ini ada dua tahap pengambilan data. Pertama, data pengukuran amplitudo getaran dengan menggunakan vibration meter. Kedua, data hasil pengujian pengukuran frekuensi pribadi kampas rem dengan metode modal analysis.

Gambar 4 menunjukkan rig pengujian rem cakram yang terdiri dari, unit penggerak, unit pengereman, dan unit pengukuran. Unit penggerak rig pengujian rem cakram berupa motor listrik berdaya $5.5 \mathrm{Hp} / 1440$ rpm dan inverter sebagai pengatur besar kecilnya putaran yang dihasilkan oleh motor listrik. Inverter dihubungkan ke motor listrik dan dari motor listrik dihubungkan ke poros (shaft) dengan menggunakan dua pulley, dan putaran pada shaft itu langsung pada piringan rem (disc). Untuk unit pengereman terdiri dari solid disc, master rem, kaliper rem, dan kampas rem (non-asbes, keramik, dan metalik). Pada unit pengukuran digunakan tachometer untuk mengukur kecepatan putaran disc yang diinginkan dan pressure gauge untuk mengukur besar tekanan pengereman.

Berikut adalah alat-alat yang dipergunakan untuk proses penelitian :

1. Vibration meter merek Lutron VB-8202

2. Sensor accelerometer

3. Tachometer

4. Impulse hammer

5. Laptop

6. DSO 2100 (Digital Storage Oscilloscope)

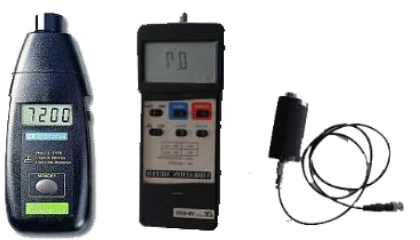

Gambar 3. (a) Tachometer (b) Vibration meter dan (c) Sensor accelerometer.

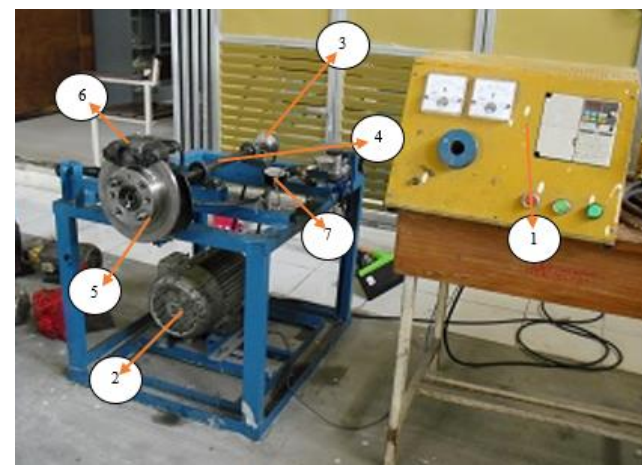

Gambar 4. Rig pengujian rem cakram.

Keterangan :

1. Inverter

2. Motor listrik

3. Pulley

4. Poros (Shaft)

\section{Tahap Pengambilan Data}

Tahap pertama yaitu pengukuran amplitudo getaran keseluruhan sistem rem cakram dengan menggunakan vibration meter. Pengujian ini dilakukan untuk mengetahui besar amplitudo getaran yang terjadi pada berbagai kondisi pengereman. Data diambil untuk setiap bahan kampas rem metalik, non-asbes, dan keramik dengan variasi kecepatan putaran piringan rem $425 \mathrm{rpm}, 637 \mathrm{rpm}, 850 \mathrm{rpm}$, dan $1062 \mathrm{rpm}$ dan variasi tekanan pengereman 0.5 bar, 1 bar, dan 1.5 bar.

Tahap kedua adalah tahap pengujian karakteristik dinamik kampas rem menggunakan metode modal analysis dengan alat impulse hammer. Pengujian ini dilakukan untuk mendapatkan nilai frekuensi pribadi dari masing-masing jenis bahan kampas rem. Data yang didapatkan dari metode ini berupa sinyal gaya yang berasal dari hammer, dan sinyal respon yang berasal dari sensor accelerometer dalam domain waktu. Dari data domain waktu tersebut kemudian sinyal diproses ke dalam domain frekuensi dan selanjutnya diproses ke dalam sinyal FRF (Frequency Response Function) dengan menggunakan Matlab. Skema modal analysis ditunjukkan pada Gambar 5 sebagai berikut : 


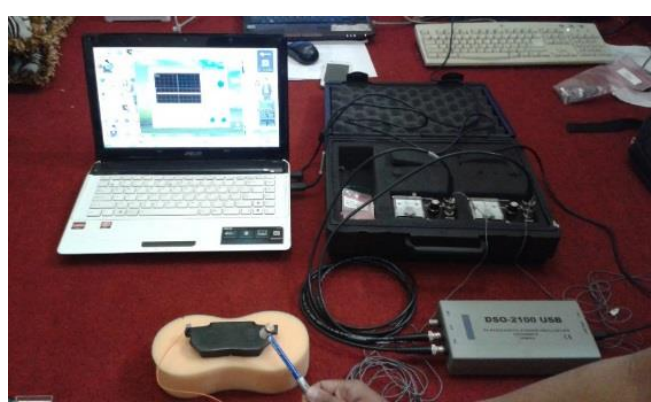

Gambar 5. Skema pengujian modal analysis.

Setelah melakukan pengambilan data dan pengujian kampas rem, kemudian dilakukan analisa data. Hasil dari pengambilan data dengan vibration meter diperoleh nilai amplitudo getaran total sistem kemudian dikaitkan hubungan antara amplitudo getaran dengan variabel-variabel penelitian seperti bahan kampas rem, kecepatan putaran piringan rem, dan tekanan pengereman. Dan hasil data pengujian modal analysis berupa frekuensi pribadi dan rasio redaman kampas rem digunakan dalam membantu menganalisa.

\section{Hasil dan Pembahasan}

Dari data vibration meter diatas, selanjutnya dianalisa untuk melihat pengaruh bahan kampas rem yang digunakan terhadap besar perubahan amplitudo getaran yang terjadi pada sistem rem cakram. Berikut adalah grafik pengaruh bahan kampas rem terhadap besar amplitudo getaran untuk berbagai tekanan pengereman :

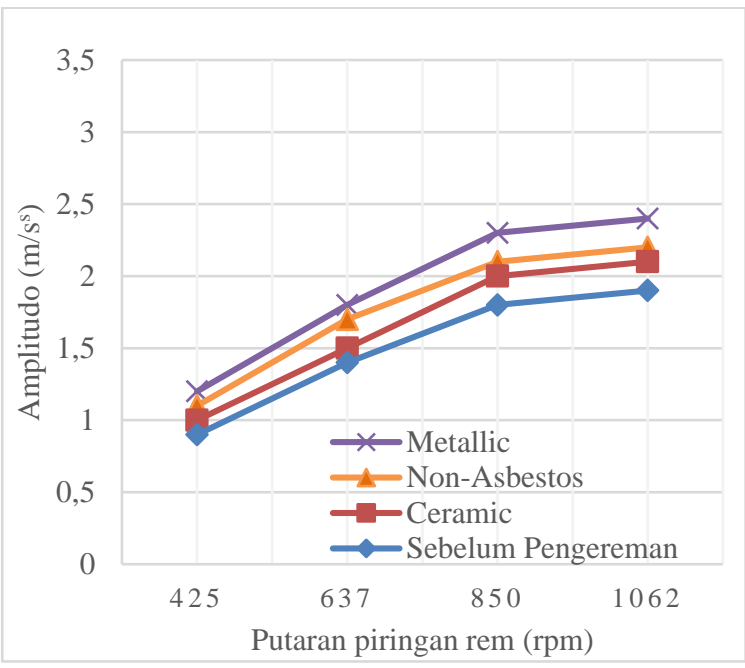

Gambar 6. Grafik hubungan antara kecepatan putaran piringan rem terhadap amplitudo getaran pada tekanan pengereman 0,5 bar.

Gambar 6 adalah grafik hubungan antara putaran piringan rem dengan amplitudo getaran pada tekanan pengereman 0,5 bar. Pada keadaan saat belum terjadi pengereman pada kecepatan putaran 425 rpm hingga $1062 \mathrm{rpm}$ amplitudo getaran sistem terus mengalami peningkatan, ini juga terjadi pada saat proses pengereman untuk pemakaian kampas rem metalik, non-asbes, dan keramik. Ketika proses pengereman dengan masing-masing bahan kampas rem tersebut, ketiganya menunjukkan bahwa semakin meningkatnya kecepatan putaran piringan rem maka akan meningkatkan gaya eksitasi yang menyebabkan nilai amplitudo getaran meningkat. Pernyataan ini juga ditunjukkan pada Gambar 7 dan 8, yang merupakan grafik hubungan antara kecepatan putaran piringan terhadap amplitudo getaran pada proses pengereman tekanan 1 bar dan 1,5 bar. Hal ini sesuai dengan penelitian yang dilakukan oleh [4] dan penelitian [2], yang menyatakan bahwa amplitudo getaran meningkat seiring meningkatnya kecepatan putaran piringan rem (disc).

Nilai amplitudo getaran sistem juga mengalami peningkatan dari keadaan belum terjadinya pengereman hingga ketika terjadi proses pengereman pada ketiga bahan kampas rem yang digunakan. Seperti yang terlihat pada Gambar 7 berikut :

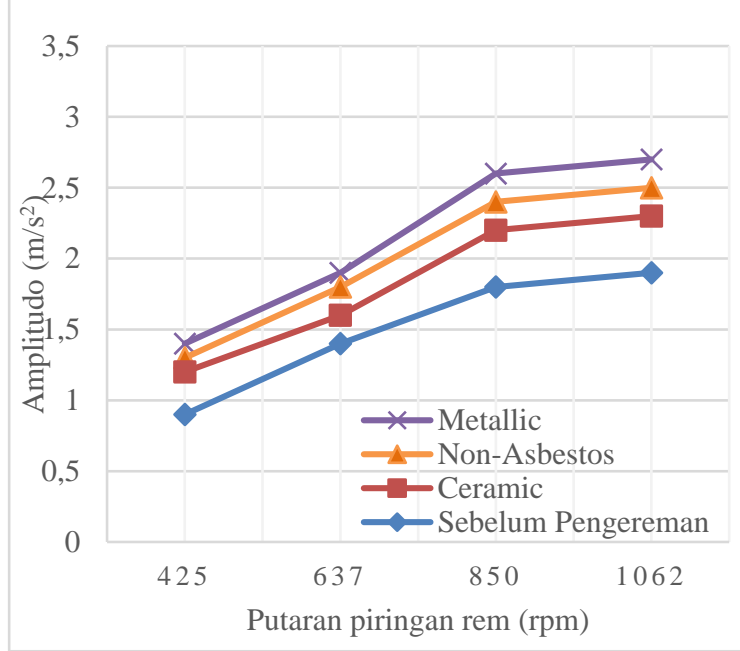

Gambar 7. Grafik hubungan antara kecepatan putaran piringan rem terhadap amplitudo getaran pada tekanan pengereman 1 bar.

Gambar 7 adalah grafik hubungan antara putaran piringan rem dengan amplitudo getaran pada tekanan pengereman 1 bar. Pada gambar diatas, peningkatan amplitudo terjadi pada kecepatan putaran $425 \mathrm{rpm}$, $637 \mathrm{rpm}, 850 \mathrm{rpm}$, dan $1062 \mathrm{rpm}$. Hal ini terjadi karena sebelum terjadi pengereman tidak ada gaya penekanan dari kampas rem terhadap piringan rem (disc) yang berputar, sehingga kontak antara kampas rem dengan piringan rem sangat ringan. Kemudian ketika mulai terjadi pengereman, piston rem akan mulai memberikan gaya pada kampas rem yang diteruskan ke piringan rem yang berputar. Dan gaya yang diberikan kampas rem akan menimbulkan gaya perlawanan dari putaran piringan rem. Dengan semakin besarnya gaya yang diberikan kampas rem terhadap piringan rem, maka kontak antara kampas rem dengan piringan rem akan besar, dan kemampuan untuk melawan pergerakan putaran piringan rem juga semakin besar sehingga menyebabkan amplitudo getaran meningkat saat proses pengereman. Pernyataan ini juga ditunjukkan pada Gambar 6 dan 
8 , yang merupakan grafik hubungan antara kecepatan putaran piringan rem terhadap amplitudo getaran pada proses pengereman tekanan 0,5 bar dan 1,5 bar. Hal ini sesuai dengan penelitian yang dilakukan oleh [5] bahwa pada tekanan nol bar getaran kecil karena kontak antara kampas rem dengan piringan rem masih sangat ringan, namun ketika diberi tekanan maka amplitudo getaran meningkat karena kontak antara kampas rem dengan piringan rem semakin besar.

Pemakaian ketiga jenis bahan kampas rem pada rem cakram memberikan pengaruh respon getaran yang berbeda-beda selama proses pengereman. Seperti yang terlihat pada Gambar 8 berikut :

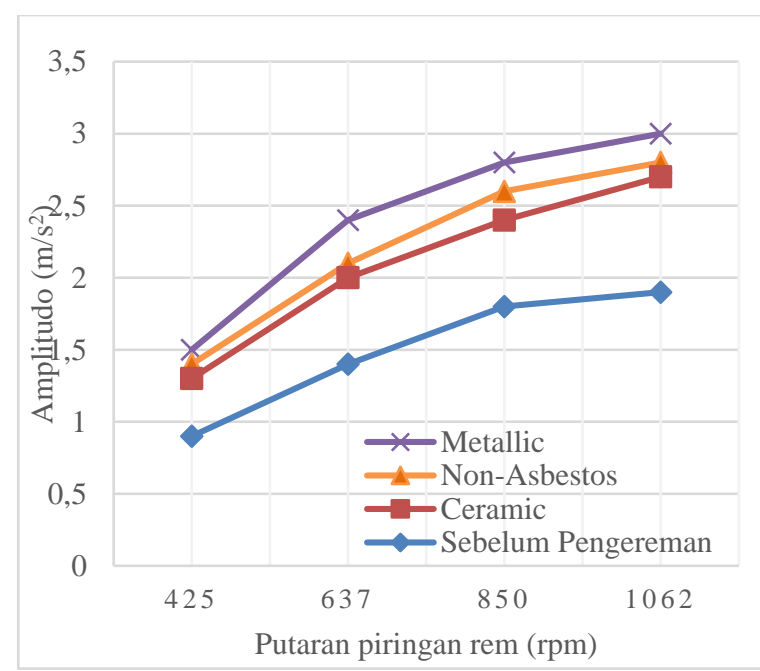

Gambar 8. Grafik hubungan antara kecepatan putaran piringan rem terhadap amplitudo getaran pada tekanan pengereman 1,5 bar.

Gambar 8 adalah grafik hubungan antara putaran piringan rem dengan amplitudo getaran pada tekanan pengereman 1,5 bar. Pada gambar diatas menunjukkan bahwa kampas rem keramik memberikan respon getaran paling rendah dibandingkan saat pemakaian kampas rem non-asbes maupun metalik, yang ditunjukkan dengan nilai amplitudo getarannya. Hal ini diperjelas dengan hasil pengujian modal analysis kampas rem. Pada kampas rem keramik nilai frekuensi pribadinya kecil dan nilai koefisien redaman kritisnya kecil, maka nilai rasio redamannya akan besar sehingga getarannya akan kecil. Dan kampas rem metalik memberikan respon getaran yang paling tinggi dibandingkan bahan kampas rem yang lain. Hal ini juga diperjelas dengan hasil pengujian modal analysis, yang menunjukkan bahwa kampas rem metalik memiliki nilai frekuensi pribadi yang besar dan nilai koefisien redaman kritis besar, maka nilai rasio redamannya akan kecil sehingga getaranya akan besar. Pengujian modal analysis ini merupakan percobaan untuk mencari frekuensi pribadi kampas rem dengan menggunakan alat impulse hammer dan perhitungan rasio redaman menggunakan metode half-power bandwidth. Sedangkan nilai koefisien redaman kritis dihitung dengan menggunakan rumus sebagai berikut :
$C_{c}=2 m \omega_{n}$

Dari hasil percobaan dan analisa perhitungan mencari frekuensi pribadi, rasio redaman, dan koefisien redaman kritis kampas rem, maka diperoleh hasil sebagai berikut :

Tabel 1. Nilai frekuensi pribadi, massa, koefisien redaman kritis, dan rasio redaman kampas rem.

\begin{tabular}{|l|l|l|l|l|}
\hline $\begin{array}{l}\text { Kampas } \\
\text { rem }\end{array}$ & $\begin{array}{l}\text { Frekuensi } \\
\text { pribadi } \\
(\mathrm{rad} / \mathrm{s})\end{array}$ & $\begin{array}{l}\text { Massa } \\
(\mathrm{kg})\end{array}$ & $\begin{array}{l}\text { Koefisien } \\
\text { redaman } \\
\text { kritis }\left(\mathrm{C}_{\mathrm{c}}\right)\end{array}$ & $\begin{array}{l}\text { Rasio } \\
\text { Redaman } \\
(\xi)\end{array}$ \\
\hline Metalik & $16.616,9$ & 0,2725 & 9056,20 & 0,0011 \\
\hline $\begin{array}{l}\text { Non } \\
\text { Asbes }\end{array}$ & $16.334,3$ & 0,2427 & 7928,66 & 0,0023 \\
\hline Keramik & $15.555,6$ & 0,2256 & 7018,67 & 0,0025 \\
\hline
\end{tabular}

Dengan nilai frekuensi pribadi yang besar maka koefisien redaman kritisnya besar sehingga kampas rem akan semakin mudah bergetar karena rasio redamannya kecil.

Selain pengaruh kecepatan putaran piringan rem pada perbedaan bahan kampas rem yang digunakan, efek tekanan pengereman juga berpengaruh terhadap amplitudo getaran pada perbedaan bahan kampas rem. Hal ini bisa dilihat pada Gambar 9 sebagai berikut :

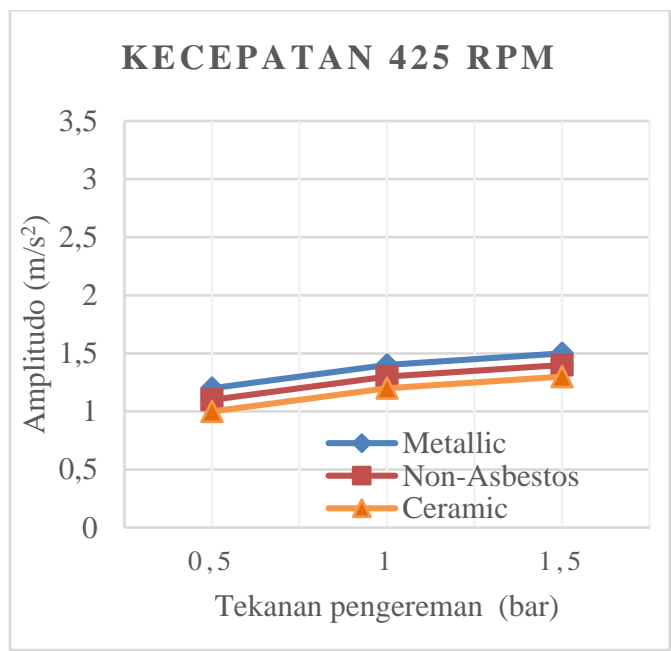

(a) 


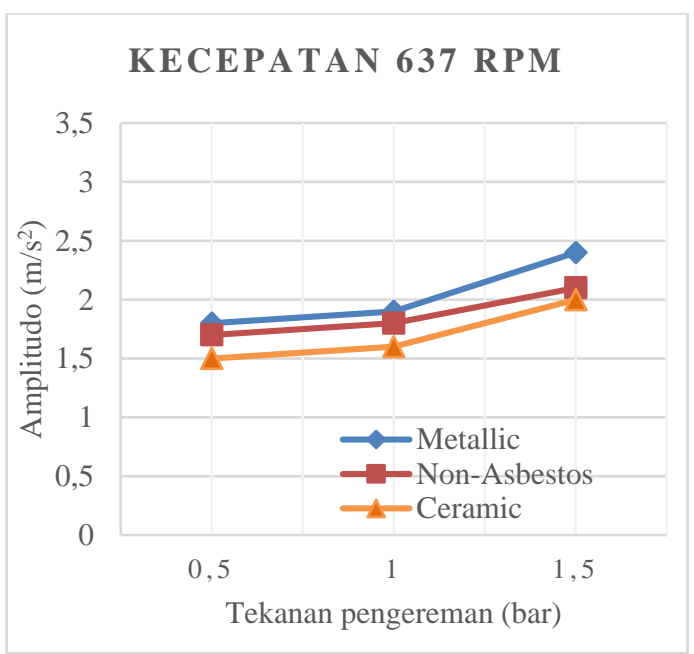

(b)

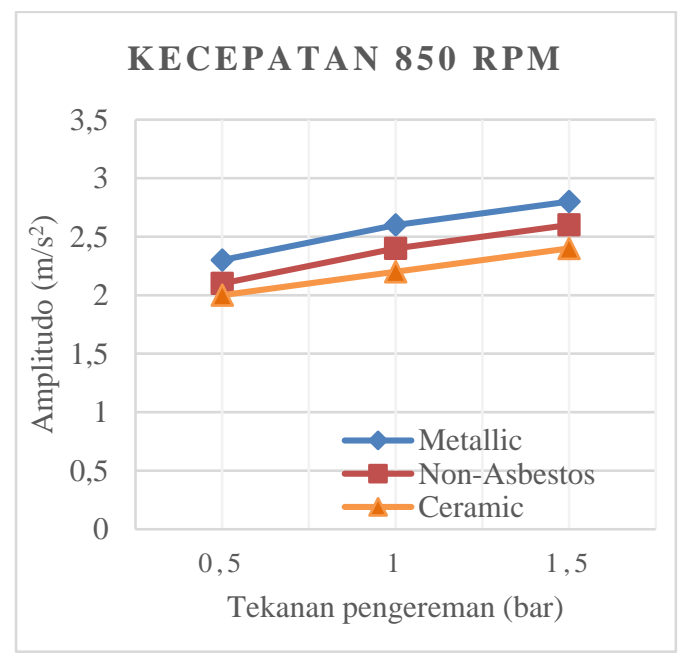

(c)

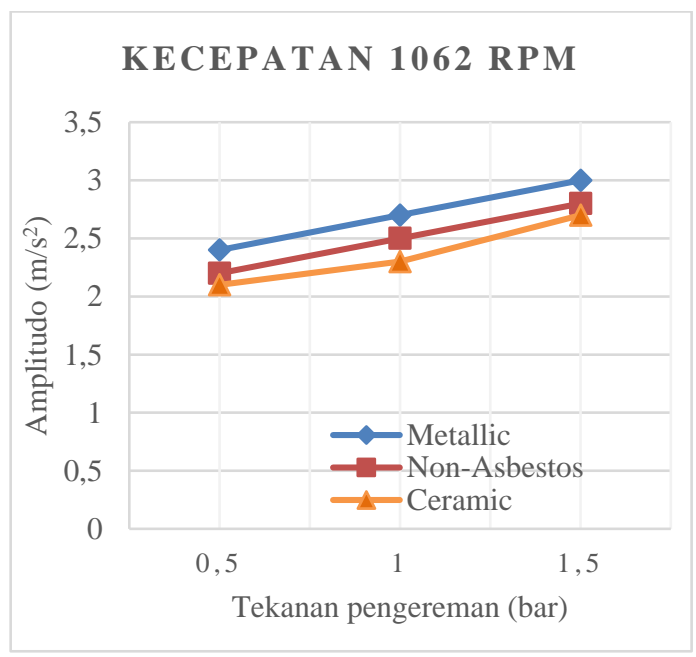

(d)

Gambar 9. Grafik hubungan tekanan pengereman terhadap amplitudo getaran pada variasi bahan kampas rem, (a) kecepatan $425 \mathrm{rpm}$ (b) kecepatan $637 \mathrm{rpm}$ (c)

kecepatan $850 \mathrm{rpm}$ (d) kecepatan $1062 \mathrm{rpm}$.

Gambar 9 adalah grafik amplitudo getaran keseluruhan sistem untuk variasi tekanan pengereman 0,5 bar, 1 bar, dan 1,5 bar pada setiap bahan kampas rem yang digunakan. Pada Gambar 9 (a) untuk kecepatan 425 rpm, pada kampas rem keramik, nonasbes, dan metalik. Dari ketiga pemakaian kampas rem diatas menunjukkan bahwa semakin besar tekanan pengereman yang diberikan, maka amplitudo getarannya juga akan membesar. Hal ini juga terjadi pada grafik kecepatan 637, 850, dan 1062 rpm yang ditunjukkan pada Gambar 9 (b), Gambar 9 (c), dan Gambar 9 (d). Hal tersebut terjadi karena semakin besar tekanan pengereman yang diberikan yang artinya gaya yang diberikan kampas rem terhadap putaran piringan rem akan semakin besar, maka akan menyebabkan bidang gesek yang terjadi pada permukaan kampas rem akan semakin besar, sehingga gaya gesek yang timbul akan meningkat. Maka kekakuan kontak antara kampas rem dengan piringan rem juga meningkat sehingga akan menyebabkan getarannya meningkat. Hal ini sesuai dengan penelitian yang dilakukan oleh [6], yang menyatakan bahwa semakin meningkatnya tekanan pengereman maka kekakuan kontak antara kampas rem dengan piringan rem juga akan semakin besar dan menyebabkan squeal meningkat.

\section{Kesimpulan}

Dari analisa data dan pembahasan dapat diambil kesimpulan sebagai berikut :

1. Jenis bahan kampas rem berpengaruh terhadap respon getaran pada sistem rem cakram. Pada kecepatan $425 \mathrm{rpm}$ dan tekanan 0,5 bar, pemakaian bahan kampas rem keramik menghasilkan nilai amplitudo getaran terendah yaitu sebesar $1 \mathrm{~m} / \mathrm{s}^{2}$, kemudian kampas rem nonasbes sebesar $1,1 \mathrm{~m} / \mathrm{s}^{2}$ dan nilai amplitudo getaran tertinggi pada pemakaian kampas rem metalik sebesar $1,2 \mathrm{~m} / \mathrm{s}^{2}$. Pemakaian bahan kampas rem keramik juga menunjukkan nilai amplitudo getaran terendah untuk semua variasi kecepatan dan tekanan pengereman.

2. Bahan kampas rem keramik memiliki nilai amplitudo terendah saat proses pengereman hal ini diperkuat dengan hasil pengujian modal analysis pada kampas rem yang menunjukkan bahwa kampas rem keramik memiliki nilai frekuensi pribadi terendah dibandingkan nonasbes dan metalik, sehingga kampas rem cenderung untuk semakin sulit bergetar karena nilai rasio redamannya besar.

3. Peningkatan putaran piringan rem dan tekanan pengereman akan meningkatkan gaya eksitasi yang menyebabkan nilai amplitudo semakin besar.

\section{Daftar Pustaka}

[1] M. Rusli, B. Mulyadi, H. Harri. 2010. Analisis getaran dan suara pada rem cakram saat beroperasi. Pros. Seminar Nasional Tahunan 
Teknin Mesin (SNTTM) ke-9, Palembang, 13-15 Oktober, MIII-11.

[2] E. Lindberg, N.-E. Horlin, P. Goransson. 2013. "An experimental study of interior vehicle roughness noise from disc brake systems." Applied Acoustics. Vol. 74, No. 3. 396-406.

[3] Y. Oura, K. Yutaka, N. Yukio, K. Kyoko. 2010. "Influence of brake pad thickness on disk brake squeal." Journal of System Design and Dynamics. Vol. 765, No. 4. 970-983.

[4] O. Giannini, A. Akay, F. Massi. 2006. "Experimental analysis of brake squel noise on a laboratory brake setup." Journal of Sound and Vibration. Vol. 292, No. 1-2. 1-20.

[5] F. Renaud, G. Chevallier, J.-L. Dion, G. Taudiere. 2012. "Motion capture of a pad measured with accelerometer during squel noise in a real brake system." Mechanical Systems and Signal Processing. Vol. 33. 155-166.

[6] Y. Oura, K. Yutaka, Y. Matsumura. 2009. "Influence of dynamic stiffness in contact region on disk brake squeal." Journal of Environment and Engineering. Vol. 4, No. 2. 234-244.

[7] G. Sheng. 2008. Friction-Induced Vibrations and Sound: Principles and Applications. CRC. 